\title{
The possibility of using Cooperative Development in pre-service teacher development
}

\author{
MARTIN BLASZK \\ JOANNA TILLACK
}

Received 20.03.2020,

received in revised form 1.08.2020,

accepted 10.08.2020.

\begin{abstract}
Cooperative Development (CD) is viewed by its creator, Julian Edge (1992), as a model of interaction to support the development of teaching professionals by which they become more aware of their practice as they are empowered to act within and upon it with increased confidence. Based upon equality and cooperation, in CD experiential understanding is valued as much as intellectual comprehension, while speaking and being listened to as aids to thinking and deeper reflection are paramount to the approach. Edge also believes that CD has a limited application in most teaching-learning situations, where equality is not usually the norm. The authors of the article, however, consider the use of $\mathrm{CD}$ with pre-service teachers during their teaching practices as an approach that, if implemented, may foster greater awareness and confidence in student-teachers as well alleviate one of the problems of the present system that exists in the Institute of English and American Studies (IEAS) at the University of Gdanss: a heavy reliance upon written documentation produced by the students which is, de facto, a way of monitoring the practices after their completion rather than providing support for students when they are involved in them. In considering whether or not teaching practices based upon
\end{abstract}


$\mathrm{CD}$ are feasible in IEAS, the following areas are examined: CD as an approach in teacher development, the level of acceptance of dialogical practices in Polish education generally, the present system of teaching practices in IEAS, data gathered from previous research connected with those practices, as well as analysis of documentation connected with their administration. Measures that would have to be undertaken if $\mathrm{CD}$ were to be implemented as an approach in support of pre-service teacher development are also considered in the discussion.

\title{
Keywords
}

Cooperative Development, pre-service teacher development, teaching practice, reflection, dialogical interaction, teaching practice journal

\section{Zastosowanie koncepcji „Cooperative Development" podczas praktyki przygotowującej do zawodu nauczyciela}

\begin{abstract}
Abstrakt
"Cooperative Development” (CD) autorstwa Juliana Edge (1992) to stymulujacy rozwój model komunikowania się pomiędzy nauczycielami, oparty na wzajemnej pomocy i wymianie doświadczeń, którego rezultatem jest zwiększona świadomość zawodowa i wiara we własne możliwości. Podstawa koncepcji CD jest równość i współpraca, słuchanie i bycie wysłuchanym. To sposób budowania relacji opartej na dialogu, partnerstwie, wspomaganiu rozwoju osobistego i naukowego poprzez refleksyjne podejście do konkretnego problemu zwiazanego $z$ praca nauczyciela. Edge jest zdania, że taki model komunikacji w relacjach nauczyciel-uczeń, które z założenia są hierarchiczne, nie wydaje się mieć większego zastosowania. Niemniej jednak, autorzy poniższego artykułu uważaja, że wprowadzenie zasad CD w Instytucie Anglistyki i Amerykanistyki w Uniwersytecie Gdańskim jako alternatywnego podejścia do praktyk studenckich przygotowujących do zawodu nauczyciela mogłoby w znacznym stopniu przyczynić się do wzrostu ich efektywności. Obecnie monitorowanie i analiza praktyk odbywa się, de facto, na podstawie dokumentacji kompilowanej po ich zakończeniu, a nie w ich trakcie. Podejście CD odwróciłoby ten proces, dając przysz-
\end{abstract}


łym pedagogom możliwość autorefleksji. Artykuł rozważa za i przeciw takiego rozwiązania.

\section{Słowa kluczowe}

Cooperative Development, rozwój osobisty nauczyciela praktykanta, praktyka nauczycielska, refleksja, komunikacja oparta na dialogu, dziennik praktyki nauczycielskiej

\section{Introduction}

The ideas considered in this paper are part of a greater research project which attempts to find an appropriate model for the preservice teacher training implemented in the Institute of English and American Studies (IEAS) - teacher specialisation, Faculty of Modern Languages, University of Gdańsk. As such, it relates to other studies concerning teacher and pre-service development for teachers of English where reflection and dialogic interaction are supported (Wallace 1993, Gabryś-Barker 2012, Edge and Mann 2013, Howard and Donaghue 2015).

The article poses the question of whether or not Cooperative Development (CD), as an approach to teacher development, could be implemented as part of the teaching practices that occur in the Institute. This consideration of $C D$ follows on from previous theoretical-empirical research carried out by one of the authors (Blaszk 2020) in which it was proposed that the teaching practices in IEAS might be viewed as a community of practice, thereby positioning them (the teaching practices) within a network of professionals all of whom would contribute to the development of the student-teachers in a mutually supportive and coherent way. However, after analysis of artefacts related to the teaching practices - student-teachers' written reflections on their practices delivered as part of a teaching practice journal (TPJ) - the possibilities of viewing the practices as a community of practice and the advantages this would offer, were percived to be negligible owing to the fragmented and diverse nature of 
the relations described by the students. As a result of this, it was felt that a more appropriate way to conceptualize the practices would be through the model of CD, which fosters development through dialogical exchange and reflection at a level of contact between individuals rather than larger groups of people.

In connection with the above, the article is ordered in the following way. First of all, CD as an approach to teacher development is described, followed by a consideration of the level of acceptance for dialogical practices in Polish education. After that, the present system of teaching practices in IEAS is presented along with data gathered from previous research into those practices. Documentation connected with the administration of the teaching practices is also described. Finally, measures that would have to be undertaken if CD were to be implemented as an approach in support of pre-service teacher development are also considered.

\section{Research methodology}

As was mentioned in the introduction, the described research is an inquiry into the form of the teaching practices in IEAS, in the Modern Languages Faculty at the University of Gdansk. It is a qualitative inquiry in that the aim is to gain a greater understanding of how the teaching practices in IEAS function. It does not, therefore, as with quantitative research, aim to prove a particular hypothesis or generate data and results that will build towards a generalized theory about pre-service teacher development. In contrast, the information it provides is meant to help the authors, as well as other members of the teacher education team working in IEAS, come to decisions about how to develop the teaching practices so that more support can be offered to student-teachers, thus enabling greater professional awareness and confidence.

The inquiry relates to previous research (Blaszk 2020) carried out between 2014 and 2017, where an attempt was made to answer the question as to whether or not the teaching 
practices might be viewed as a community of practice, in which case it would be plausible to construct a model of practice that could use the networks ensuing from the community to support pre-service teachers in the development of a teacher Self. Analysis of data collected from 90 texts created by student-teachers from three cycles of didactics practices (2014-2015, 2015-2016, 2016-2017), showed that there was not one community of practice but rather that each student-teacher was involved in a particular version of a teaching practice, some of which could be viewed to be a community of practice, while others could not. Bearing this in mind, it was suggested that a more appropriate model to exploit for purposes of the teaching practices in IEAS, would be one that is based upon Cooperative Development, which is a dialogical and reflective approach that works on an individual level rather than that of a networked community. This article refers to data gathered from the previous research (Blaszk, 2020) based upon the analysis and interpretation of artefacts (comments written by student-teachers in TPJs), as well analysis of documentation connected with the format (Praktyki nauczycielskie 2019) and administration of the practices (Instrukcja Postępowania 2019) to try and gain an answer to the question of whether teaching practices in IEAS based upon CD are feasible. As with the previous research, this inquiry takes the form of a case-study in that it concerns a particular group of people involved in a particular activity (Wilczyńska and Michońska-Stadnik 2010: 154). It is also a form of action research where structured reflection concerning a particular issue involves questioning and data collection, with the resulting ideas and solutions being applied to further professional action (Wallace 2008: 14). 


\section{Teaching practices in the light of Cooperative Development}

Cooperative Development is seen by its author, Julian Edge (1992: 1) as a practice that helps build the confidence of participants as it empowers them. This is because, through its implementation, participants become:

(a) aware of their own and other people's strengths and skills,

(b) increasingly able to listen attentively to others,

(c) responsive to their own teaching needs and situation.

Fundamental to achieving this is an equal status cooperation with other teachers and learners, with whom "experiences and opinions" can be shared, thereby to "escape from simple, egocentric subjectivity, without chasing after a non-existent objectivity" (Edge 1992: 4). In CD, there is also an acceptance of experiential understanding in addition to intellectual comprehension, so that the emotional process of learning is emphasised along with the cognitive. Importantly, speaking is viewed to be central to the whole enterprise as it allows us to formulate our ideas and, as a result, see how coherent those ideas are.

\subsection{The Speaker, the Understander and the Observer}

In the implementation of Cooperative Development, the above considerations have definite implications for its form. In each CD encounter, there is a Speaker, an Understander, and there may also be an Observer. The pattern of interaction is as follows. The Speaker elicits the help of an Understander. The Speaker expresses her/himself to the Understander who helps her/him to develop "ideas by clarifying them and following them where they lead" (Edge 1992: 7). In the initial implementation of CD, there may also be an Observer, whose role is to take part in the Speaker/Understander discussions and give feedback as a "third perspective" (Edge 1992: 16). Also, in connection with 
the Speaker/ Understander interactions, Edge outlines new norms for interaction between two people. The usual arena of discussion, in which the speaker with the strongest arguments dominates, is replaced by a situation in which the Speaker is given as much space as possible to develop her/his ideas, while the Understander does all she/he can "to help the Speaker to use that space creatively" (Edge 1992: 10). For this to occur successfully, there are some underlying principles that need to be adhered to. First, there is respect, which means that the Understander accepts decisions made by the Speaker in relation to what is to be talked about and acted upon. The Understander must also be non-judgmental: she/he must accept what the Speaker says and "bracket" her/his knowledge and values for the period of the exchange. Edge (1992: 11) recounts this in the following way:

Colleagues have every right to their views on teaching and students; they come out of their own experience and understanding. Development can only take place when Speakers recognise their own real views, and then see something in there which they wish to investigate, or to take further, or to change. Mutual, non-evaluative respect is fundamental to Cooperative Development.

In addition to respect, empathy is also of vital importance. The Understander has to see the Speaker's teaching situation according to the Speaker's frames of reference. This means there will be requests for clarification throughout the exchange, enabling the Speaker to get the best possible view of what she/he is doing, so that decisions can be made about what to do next. As well as respect and empathy, honesty is also an important aspect of the exchanges that take place during CD. However, honesty here does not mean the Understander says exactly what she/he thinks in response to comments made by the Speaker. On the contrary, the Understander is guided by respect and empathy to accept what the Speaker says even if she/he (the Understander) does not agree with it; this is because the 
Understander's main purpose is to try and help the Speaker by aiding self-reflection and following on from that (as a result of it), understanding and development.

\subsection{Stages, techniques and abilities}

As well as the conditions given above, there are also a number of techniques to be used and abilities to be developed to ensure the proper functioning of $\mathrm{CD}$ at its different stages. These include the use of attending, reflecting and focusing by the Understander to encourage exploration by the Speaker; the facilitation of discovery in the Speaker through the implementation of thematising, challenging and disclosing by the Understander; and, putting into action the ideas that arise during the interaction of Speaker and Understander, through the use of goal-setting, trialling and planning. More fully, during the different stages, the techniques/abilities used can be described as follows:

Exploration stage (Understander is circumspect, supportive) (Edge 1992: 21-44):

- attending - the Understander knows how to read and send bodily and verbal signals, so that the Speaker will feel encouraged to engage fully in the exchange that takes place,

- reflecting - the Understander acts as a mirror, to repeat what the Speaker has said (through the use of direct quotation or paraphrase), so that important issues might be given further and more in-depth consideration,

- focusing - the Understander asks the Speaker to review what she/he has said and choose a point to pursue more fully or simply recapitulates a point that the Speaker has mentioned and ask her/him to comment upon it further.

Discovery stage (Understander is more active, "interventionist") (Edge 1992: 45-64): 
- thematising - the Understander perceives themes arising in what the Speaker is saying and brings them to the Speaker's attention for comment or further development,

- challenging - the Understander hears the Speaker utter what appear to be contradictory statements on the same issue and challenges the Speaker about these two different points of view,

- disclosing - the Understander may disclose his/her own experiences of teaching, however, this is "only to the extent that it may be useful to clarify exactly what the Speaker is trying to say [...] as a source of comparison or contrast" (Edge 1992: 61).

Action stage (Understander facilitates the Speaker to put ideas into action) (Edge 1992: 65-77):

- goal-setting - the Understander and Speaker formulate a goal that can be realised in terms of "a next step [...] in the investigation of professional activity" (Edge 1992: 66),

- trialling - the Speaker provides a spoken rehearsal of what is to be done to achieve a particular goal while the Understander points out details that may have been overlooked: the trialling is to help produce a flexible plan for action - one which allows for unforeseen incidents and in which mistakes have a place, ${ }^{1}$

- planning - administrative details are decided upon concerning observations of classes by the Understander, contingent

1 As Edge (1992: 72) writes: "if I am not able to carry out my plan in one particular class, I don't want to spend my time and energy getting too frustrated about it. I want to learn from the unexpected thing that got in my way. Next time I talk to my Understander, I shall try to focus on this event for a while before I move on to set my new goal for the next lesson [...]." The emphasis here appears to be on the creation of a procedure in which variation is catered for and dealt with as part of the teaching / developmental process. Further, in the same chapter, Edge comments upon the role of mistakes in teaching and how they are dealt with in $\mathrm{CD}$, hinting at the fact that it is the Speaker's interpretation of events that must always take precedence: "In the area of trialling, it can be particularly difficult for the Speaker not to ask for advice or opinions. Again the fundamentals of this style of cooperation are at issue. As Speaker, I am looking to develop myself to be the best teacher $I$ can be. What sounds like a mistake to someone else might not be a mistake for me. If I do plan something that goes wrong, I can live with that and learn from it. The lessons that I learn will also be my own" (72). In this situation, therefore, mistakes are not negative but, if recognised by the Speaker and acted upon, play an important role in her/his (self-)development. 
research by the Speaker, or further meetings between the Speaker and the Understander: this stage ensures that the process of $\mathrm{CD}$ is maintained and continues to grow.

\subsection{Activities}

Besides an outline for the functioning of $\mathrm{CD}$, Edge also provides a range of useful activities to be used in the preparation of each stage of its realization. These include, among others:

\section{Exploration stage:}

- observation and interpretation of body language - exploration (Edge 1992: 24-25),

- statements about teaching to be reflected upon - reflecting (Edge 1992: 31-32),

- completion of questionnaire to be discussed - focusing (Edge 1992: 40-44).

\section{Discovery stage:}

- description of self linked to meditation - thematising (Edge 1992: 49-52),

- consideration of self in relation to team role stereotypes - challenging (Edge 1992: 55-57),

- completion of a motivations table for self and others - disclosing (Edge 1992: 62-64).

\section{Action stage:}

- completion of sentences about one's own teaching used as the basis for a Speaker, Understander, Observer interaction - goal setting (Edge 1992: 69-70),

- trialling goals which have been set - trialling (Edge 1992: 7175),

- planning the continuation of Cooperative Development - planning (Edge 1992: 76-77). 
In a number of cases, for various stages of $C D$, the activities described are also complemented by Edge's commentaries in which examples of the language to be used by the Understander, Speaker or Observer are given (see, for example, Edge 1992: 29, 67). Edge also provides a number of salient comments on the implementation of the approach in connection with mutually agreed signals (physical and verbal) to facilitate the smooth running of the Understander-Speaker exchange (Edge 1992: 16, 1718 ), the role of silence and the accuracy of reflection (31), refraining from giving advice on the part of the Understander (Edge 1992: 47) even if the Understander does not agree with the Speaker's views (Edge 1992: 23) and the fact that the exchange allows the Understander opportunities to grow and develop as much as the Speaker (Edge 1992: 72).

\section{CD in the context of Polish higher education}

At present, reflection-based and dialogic interactions are in use in Polish higher education. In Gdańsk and other universities across Poland, there is support for a greater partnership between those involved in the teaching-learning process in the form of tutoring (Karpińska-Musiał 2016, Karpińska-Musiał 2017), while in connection with second language education (SLE) specifically, there are a number of inquiries into pre-service teacher development in which reflective and dialogic processes are analyzed and promoted (Gabryś-Barker 2012, Lankiewicz 2015, Werbińska 2017).

With regard to the use of CD in the Polish education system, Edge's initial publication was, in part, the result of workshops carried out with groups of teachers across the world, including Poland (Edge 1992: 1). Additionally, the theories which underpin CD are also known to and employed in SLE in Poland; a number of the researchers cited by Edge and the themes they pursue also appear in the volumes given above, in connection with inquiries into pre-service teacher development. The researchers and themes include, among others: Freire (1972) and 
the socio-political issues underlying education, Lakoff and Johnson (1980) and the expression and comprehension of experience through language, Underhill (1989) and the application of humanistic approaches, Nunan (1989a) and Wright (1987) and (re)defining roles in teacher development, and Nunan (1989b) in terms of the relationships that exist within the developmental encounter.

Do the uses of shared types of interaction and a concern with similar themes between Edge and Polish SLE researcherteachers, mean that there are grounds for CD to be used in preservice teacher development in IEAS? To answer this question, it is necessary to consider the local factors that may have an impact upon whether or not it is possible to implement the model, as well as to review a number of important issues underlying Edge's conception of CD.

\subsection{Local factors}

With regard to the possibility of implementing CD as a model for pre-service teacher development in IEAS, a model for teacher development that is currently used in the Institute will now be described to determine whether or not $\mathrm{CD}$ would provide extra value over and above what is currently offered. In connection with this, guidelines provided at the faculty level (Instrukcja Postępowania 2019) and directives from the Ministry of Education (Dziennik Ustaw Rzeczypospolitej Polskiej 2019) will also be considered.

In the Institute of English and American Studies (IEAS), the system established for the teaching practices undertaken by first level day students on the teacher specialization course is as follows. Approximately 30 students a year participate in practices in which they undergo 150 contact hours with a school of their choice. In doing so, the students are involved in 30 hours of General Pedagogical Practice (GPP), where they analyse and take part in the general running of a school as observers, followed by 120 hours of Didactic Practice (DP), in which they 
complete 40 hours of observation and 80 hours of teaching. In connection with IEAS, the teaching practices are officially recognized in the plan of studies where they are allocated to the second semester (GPP) and third, fourth and fifth semesters (DP) (see positions 30 and 53 - Plan Studiów, 2019). Time is also designated for the practices in each semester timetable so that the students can go into schools to carry out the practices. This time is usually blocked together in one day or part of a day (morning or afternoon) and scheduled for the beginning or end of the week - Monday or Friday. ${ }^{2}$ Students can also negotiate individually with the school in which they carry out their DP to do part of the practices in September, when there are no lectures or classes taught at the University - see Table 1.

Additionally, there are two members of the academic staff who are assigned to oversee the teaching practices overall. Their functions are given as director of practices and supervisor of practices. ${ }^{3}$ The director's job is to liaise between the students and the university administration to ensure that the bureaucratic documentation relating to the setting up and smooth running of the practices is completed correctly and that the students are informed of any changes in the documentation or rules and regulations relating to the practices. The documentation consists of, among other items, a contract between the student and the school for the time the students are involved in their practices, insurance for the students and an invoice to be completed by the school mentor for the consultation hours they work with the student-teacher (Instrukcja postępowania 2019). The rules and regulations are issued by the Ministry of

2 At the time of writing, the blocks of time devoted to teaching practices on the plan of subjects for students involved in the teacher specialization are Mondays 8:00 - 13:00 for second year students and Fridays 8:00 - 13:00 for third year students. First year students do not have a block of time dedicated to fulfilling their GPP, although Thursday mornings are free between 08:00 11:30 (Plan zajęc - stacjonarne, 2020) and it is expected that they might use this time to carry out their practices .

3 The titles in Polish are "kierownik praktyk" and "opiekun praktyk" respectively. 
Education (Dziennik Ustaw Rzeczypospolitej Polskiej 2019) and procedural guidelines are offered at the faculty level (Instrukcja postępowania 2019). The rules and regulations touch upon the legally binding form and content of the teaching practices while the procedural guidelines provide an interpretation and ideas concerning the implementation of that form and content. In addition to the bureaucratic documentation, the director of the practices also collects assessment results from the supervisor of practices and ensures it is posted on the University's electronic system of results. An overview of the administrative documents necessary for both the GPP and DP and who is responsible for completing and/or signing them is given in Table 2 .

\section{Table 1}

The type of teaching practice, when it takes place, the number of hours to be done and what needs to be done

\begin{tabular}{|c|l|l|}
\hline What? & \multicolumn{1}{|c|}{$\begin{array}{c}\text { General Pedagogical } \\
\text { Practice }\end{array}$} & \multicolumn{1}{c|}{ Didactic Practice } \\
\hline When? & $\begin{array}{l}\text { Semester 2 } \\
\text { Mondays or Fridays allo- } \\
\text { cated for teaching prac- } \\
\text { tices (or part of those } \\
\text { days - usually mornings) }\end{array}$ & $\begin{array}{l}\text { Semesters 3, 4 and 5 } \\
\text { Mondays or Fridays allo- } \\
\text { cated for teaching prac- } \\
\text { dices (or part of those }\end{array}$ \\
& $\begin{array}{l}\text { September may also be } \\
\text { used by some student- } \\
\text { teachers to carry out } \\
\text { their teaching practices }\end{array}$ \\
\hline $\begin{array}{c}\text { Number of } \\
\text { hours / } \\
\text { needs to } \\
\text { be done? }\end{array}$ & $\begin{array}{l}\text { 30 hours - Participation } \\
\text { and Observation } \\
\text { Student-teachers take } \\
\text { part in and observe the } \\
\text { general running of a } \\
\text { school }\end{array}$ & $\begin{array}{l}\text { 40 hours - Observation } \\
\text { Student-teachers observe } \\
\text { their mentor (and possi- } \\
\text { bly other teachers) teach- } \\
\text { ing }\end{array}$ \\
\hline
\end{tabular}


Table 2

Administrative documents necessary for both the GPP and DP and who is responsible for completing and/or signing them

\begin{tabular}{|c|c|c|c|}
\hline Item & $\begin{array}{c}\text { Description of } \\
\text { documents to be } \\
\text { completed and/or } \\
\text { signed }\end{array}$ & Practice type & $\begin{array}{l}\text { Completed, kept } \\
\text { on file and/or } \\
\text { signed by }\end{array}$ \\
\hline 1 & $\begin{array}{l}\text { Application form - } \\
\text { student-teacher } \\
\text { request to con- } \\
\text { duct teaching } \\
\text { practices } \\
\text { Skierowanie na } \\
\text { praktyki obowią- } \\
\text { kowe }\end{array}$ & $\begin{array}{l}\text { One document for } \\
\text { both GPP/DP }\end{array}$ & $\begin{array}{l}\text { student-teacher, } \\
\text { director of } \\
\text { practices, } \\
\text { university } \\
\text { administration/ } \\
\text { dean }\end{array}$ \\
\hline 2 & $\begin{array}{l}\text { Agreement be- } \\
\text { tween the school } \\
\text { and the university } \\
\text { - enables the stu- } \\
\text { dent-teacher to } \\
\text { conduct teaching } \\
\text { practices for } \\
\text { a definite or } \\
\text { indefinite period } \\
\text { of time } \\
\text { Porozumienie na } \\
\text { czas określony / } \\
\text { nieokreślony } \\
\text { w sprawie } \\
\text { prowadzenia } \\
\text { praktyk } \\
\text { obowiazkowych } \\
\text { przygotowujacych } \\
\text { do wykonywania } \\
\text { zawodu } \\
\text { nauczyciela }\end{array}$ & $\begin{array}{l}\text { One document for } \\
\text { both GPP/DP }\end{array}$ & $\begin{array}{l}\text { school } \\
\text { administration/ } \\
\text { director, director } \\
\text { of practices, } \\
\text { university } \\
\text { administration/ } \\
\text { dean }\end{array}$ \\
\hline
\end{tabular}




\begin{tabular}{|c|c|c|c|}
\hline 3 & $\begin{array}{l}\text { Insurance form - } \\
\text { insurance for the } \\
\text { student-teacher } \\
\text { Formularz } \\
\text { ubezpieczenia }\end{array}$ & $\begin{array}{l}\text { One document for } \\
\text { both GPP/DP }\end{array}$ & $\begin{array}{l}\text { school } \\
\text { administration/ } \\
\text { director, student- } \\
\text { teacher, director } \\
\text { of practices, } \\
\text { university } \\
\text { administration/ } \\
\text { dean }\end{array}$ \\
\hline 4 & $\begin{array}{l}\text { Contract - be- } \\
\text { tween the mentor } \\
\text { and the university } \\
\text { Umowa zlecenie }\end{array}$ & $\begin{array}{l}\text { One document or } \\
\text { more - GPP/DP - } \\
\text { depending on } \\
\text { number of men- } \\
\text { tors }\end{array}$ & $\begin{array}{l}\text { mentor, university } \\
\text { administration/ } \\
\text { dean }\end{array}$ \\
\hline 5 & $\begin{array}{l}\text { Document provid- } \\
\text { ing personal de- } \\
\text { tails of the mentor } \\
\text { for tax and insur- } \\
\text { ance purposes } \\
\text { Oswiadczenie zle- } \\
\text { ceniobiorcy dla ce- } \\
\text { lów podatkowych } \\
\text { i ubezpieczenio- } \\
\text { wych }\end{array}$ & $\begin{array}{l}\text { One document or } \\
\text { more - GPP/DP - } \\
\text { depending on } \\
\text { number of men- } \\
\text { tors }\end{array}$ & mentor \\
\hline 6 & $\begin{array}{l}\text { Certificate of men- } \\
\text { tor's earnings for } \\
\text { National Insur- } \\
\text { ance purposes } \\
\text { (completed by the } \\
\text { mentor's employer } \\
\text { - the school) } \\
\text { Zaświadczenie } \\
\text { o uzyskanych } \\
\text { dochodach ZUS }\end{array}$ & $\begin{array}{l}\text { One document or } \\
\text { more - GPP/DP - } \\
\text { depending on } \\
\text { number of men- } \\
\text { tors }\end{array}$ & $\begin{array}{l}\text { school } \\
\text { administration/ } \\
\text { director }\end{array}$ \\
\hline 7 & $\begin{array}{l}\text { Record of teaching } \\
\text { practices } \\
\text { Dzienniczek } \\
\text { praktyki } \\
\text { studenckiej }\end{array}$ & $\begin{array}{l}\text { One for both } \\
\text { GPP/DP }\end{array}$ & $\begin{array}{l}\text { mentor, student- } \\
\text { teacher, director } \\
\text { of practices, } \\
\text { university } \\
\text { administration }\end{array}$ \\
\hline
\end{tabular}




\begin{tabular}{|c|l|l|l|}
\hline 8 & $\begin{array}{l}\text { Mentor opinion - } \\
\text { overall assess- } \\
\text { ment of practice } \\
\text { by mentor } \\
\text { Ocena przebiegu } \\
\text { praktyki studenc- } \\
\text { kiej }\end{array}$ & $\begin{array}{l}\text { One each for } \\
\text { GPP/DP }\end{array}$ & $\begin{array}{l}\text { mentor, } \\
\text { director of prac- } \\
\text { tices, } \\
\text { supervisor }\end{array}$ \\
\hline 9 & $\begin{array}{l}\text { Document con- } \\
\text { firming successful } \\
\text { completion of } \\
\text { practice } \\
\text { Karta zaliczenia } \\
\text { praktyk }\end{array}$ & $\begin{array}{l}\text { One each for } \\
\text { GPP/DP }\end{array}$ & $\begin{array}{l}\text { student-teacher, } \\
\text { director of } \\
\text { practices, } \\
\text { university } \\
\text { administration }\end{array}$ \\
\hline 10 & $\begin{array}{l}\text { Completed bill of } \\
\text { payment for } \\
\text { mentor's } \\
\text { participation in } \\
\text { practices } \\
\text { Rachunek }\end{array}$ & $\begin{array}{l}\text { One document or } \\
\text { more - GPP/DP - } \\
\text { depending on } \\
\text { number of } \\
\text { mentors GPP/DP }\end{array}$ & $\begin{array}{l}\text { mentor, director } \\
\text { of practices, dean, } \\
\text { university } \\
\text { administration }\end{array}$ \\
\hline 11 & $\begin{array}{l}\text { Record of } \\
\text { consultation } \\
\text { hours completed } \\
\text { during final } \\
\text { month of each } \\
\text { practice: GPP - } \\
\text { 4h; DP - 16h } \\
\text { Miesieczna } \\
\text { ewidencja godzin }\end{array}$ & $\begin{array}{l}\text { One document } \\
\text { with separate } \\
\text { entries for } \\
\text { GPP/DP }\end{array}$ & $\begin{array}{l}\text { mentor, student- } \\
\text { teacher, director } \\
\text { of practices, } \\
\text { university } \\
\text { administration }\end{array}$ \\
\hline
\end{tabular}

The supervisor, meanwhile, liaises with the director and students to create materials that can be exploited by the students in support of their teaching practices (GPP and DP). These materials include, among other items, assessment forms of student performance (completed by the school mentor), a record of each hour of observation and teaching that the student-teacher carries out (completed by the student-teacher), tasks to be done during the teaching practices (completed by the studentteacher) and overall reflections on the teaching practices 
(completed by the student-teacher). The materials for the GPP and DP, a full list of which are given below in Table 3, are made available to the student-teachers on the Institute website (Praktyki nauczycielskie 2019). The supervisor also assesses the Teaching Practice Journals (TPJs) that the students complete and hand in for both the GPP and DP. The TPJ contains the materials listed above, which the student-teachers and school mentors react to and/or complete throughout the different stages of the teaching practices.

Table 3

Material for TPJs to be completed by either the school mentor or student-teacher during the teaching practices - GPP and DP

\begin{tabular}{|c|l|l|l|l|}
\hline Item & $\begin{array}{c}\text { General } \\
\text { Pedagogical } \\
\text { Practice }\end{array}$ & $\begin{array}{l}\text { Completed } \\
\text { /supplied by }\end{array}$ & $\begin{array}{l}\text { Didactic } \\
\text { Practice }\end{array}$ & $\begin{array}{l}\text { Completed } \\
\text { /supplied by }\end{array}$ \\
\hline 1 & $\begin{array}{l}\text { Mentor } \\
\text { opinion - } \\
\text { overall } \\
\text { assessment } \\
\text { of practice by } \\
\text { mentor }\end{array}$ & $\begin{array}{l}\text { School men- } \\
\text { tor }\end{array}$ & $\begin{array}{l}\text { Mentor } \\
\text { opinion - } \\
\text { overall } \\
\text { assessment } \\
\text { of practice by } \\
\text { mentor }\end{array}$ & $\begin{array}{l}\text { School } \\
\text { mentor }\end{array}$ \\
\hline 2 & $\begin{array}{l}\text { Record of } \\
\text { involvement } \\
\text { in the life of } \\
\text { the school } \\
\text { (30 hours) }\end{array}$ & $\begin{array}{l}\text { Student- } \\
\text { teacher }\end{array}$ & $\begin{array}{l}3 \text { lesson } \\
\text { evaluations }\end{array}$ & $\begin{array}{l}\text { School } \\
\text { mentor }\end{array}$ \\
\hline 3 & & Student- & $\begin{array}{l}\text { Record of ob- } \\
\text { servation (40 } \\
\text { hours) and } \\
\text { teaching (80 } \\
\text { hours) done }\end{array}$ & $\begin{array}{l}\text { Student- } \\
\text { teacher }\end{array}$ \\
\hline 4 & teacher & $\begin{array}{l}\text { Syllabus } \\
\text { /course } \\
\text { content } \\
\text { information }\end{array}$ & $\begin{array}{l}\text { Student- } \\
\text { teacher }\end{array}$ \\
\hline 5 & $\begin{array}{l}\text { Overall } \\
\text { comments }\end{array}$ & $\begin{array}{l}\text { Student- } \\
\text { teacher }\end{array}$ & $\begin{array}{l}\text { Examples of } \\
5\end{array}$ & $\begin{array}{l}\text { Student- } \\
\text { teacher }\end{array}$ \\
\hline
\end{tabular}




\begin{tabular}{|c|c|c|c|}
\hline & $\begin{array}{l}\text { on the } \\
\text { general } \\
\text { pedagogical } \\
\text { practices }\end{array}$ & $\begin{array}{l}\text { observation } \\
\text { tasks - } \\
\text { written up }\end{array}$ & \\
\hline 6 & & $\begin{array}{l}\text { Examples of } \\
5 \text { lesson } \\
\text { plans, } \\
\text { materials } \\
\text { used in } \\
\text { lessons and } \\
\text { self- } \\
\text { assessment } \\
\text { commentary } \\
\text { - written up }\end{array}$ & $\begin{array}{l}\text { Student- } \\
\text { teacher }\end{array}$ \\
\hline 7 & & $\begin{array}{l}\text { Overall } \\
\text { comments } \\
\text { on the } \\
\text { didactic } \\
\text { practices }\end{array}$ & $\begin{array}{l}\text { Student- } \\
\text { teacher }\end{array}$ \\
\hline
\end{tabular}

\section{Discussion - reasons for and against the implementation of Cooperative Development}

\subsection{The success of the present system}

At the Institute level, the existing system established for monitoring and evaluating the practices is generally perceived to be successful. The majority of students complete their practices within the prescribed

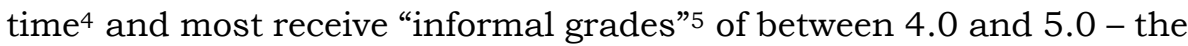

4 The hand-in date for the GPP is usually the end of the second semester in the first week of June. The hand-in date for the DP is usually the end of the fifth semester in the third week of January.

5 The official grades given for successful completion of the teaching practices are either a "pass" for successful completion or a "fail" for unsuccessful completion. In addition to this, however, for the DP a non-statutory grade is awarded by the supervisor of practices. This relates to the scale commonly used at university level where 5.0 denotes the top grade possible and 2.0 is a fail. The scaled grade along with written comments given on a feedback form are meant to orientate students about the strengths and weaknesses of their performance in connection with the presented documentation in their TPJ. 
upper end of the scale for the scheme of assessment used by the University. In addition, certain forms of documentation and procedures have been recognized at the faculty level as "good practice" and have been given as a model for departments of other languages to follow where teaching practices are implemented. ${ }^{6}$

\subsection{The failure of the present system}

In spite of the above mentioned success, the teaching practices as they currently exist are not without their problems. In connection with previous research (Blaszk, 2020), student reactions to the teaching practices vary and can be summed up in the following way:

- a rewarding and developmental process,

- beneficial but with some difficulties,

- a problematic experience, with few benefits.

And, although overall the majority of students involved in the teaching practices belong to the first two categories rather than the final one, there is still dissatisfaction related to:

- the bureaucracy connected with carrying out their practices in a school,

- the amount of paperwork the students have to complete as part of the formal assessment of their practices (students have to complete and ensure the correct completion of documentation between the school in which they carry out their practices and the University, as well as write up and hand in the TPJs for their GPP and DP).

- the difficult relations they had with mentor teachers,

- the mismatch between what they were taught in their didactic course at the university and what they experienced in the classroom at school.

${ }^{6}$ In 2014, two documents were recommended for adoption by other departments in the Faculty of Modern Languages by the vice-dean responsible for student practices: the Mentor opinion, where the mentor provides an overall assessment of the student-teacher's practice, and the Record of teaching practices, in which student-teachers give details of the school(s) and mentor(s), as well as the dates of their practices. Both of these documents were created by the academic staff responsible for the teaching practices in IEAS. 


\subsection{The positive aspects of implementing Cooperative Development}

Taking into account these "problems", a scheme of CD might offer an alternative to the amount of paperwork to be completed by students, as it offers a scheme of verbal interaction and reflection that could be used instead of the TPJs. It might also go some way to help students to view the practice in schools not simply as the application of methods and activities presented and explored on a taught course (i.e., the didactics course), but also as an active involvement in which they, personally, have some influence.

The supported discussion and reflection of $C D$ connected to the involvement and development of students as teachers would also fulfil another area which the present system aims to support but does not fully realize: the development of a greater selfawareness (reflection) in the students of the processes they are involved in. In part, the TPJs aim to facilitate this and make it an element of the practices by offering 20 descriptive-reflective observation tasks that the students have to use and complete throughout the observations of the DP (Appendix 1). There is also a Self-evaluation section to be completed after each lesson taught (Appendix 2) and an Overall Comments section to be written up first after the GPP has been completed and then after the DP (Appendix 3). Each of the tasks and the two sections uses a series of questions to help the students to uncover different aspects of what they have experienced. However, it has been the experience of one of the authors of this article, as the person officially designated to review (and assess) the TPJs, that while some students are engaged in the reflection process by writing up their experiences and through that gain a deeper perspective on their thoughts, other students find it difficult to go beyond description and give either cursory answers or neglect to fully complete certain parts of the journal, usually the observation tasks. It is the belief of the authors of this article, therefore, that involvement in the continuous and personalized 
dialogical process that the face-to-face encounter of $\mathrm{CD}$ offers, would do more to ensure the growth of self-awareness in student-teachers with regard to the teaching-learning processes that they are involved in within the school setting.

\subsection{A reason against implementation - Edge's conception of Cooperative Development}

Cooperative Development is, first and foremost, about teacher development, where colleagues already involved in the profession want to help one another to do the best they can in their chosen field. Meanwhile, to achieve this, it is understood by the people involved in the process (Speaker, Understander, Observer) that they are acting together as equal partners and that change or innovation for their own sake are not the underlying goals, although these may occur if the Speaker perceives a need for them. When it comes to pre-service teacher training, therefore, the possibilities for its use would appear to be complicated (restricted) by the fact that the relationship between trainer and trainee is most often an asymmetrical one; where the trainer is an expert in the field of teaching and the trainee is a novice who wants to learn about it from the experienced and knowledgeable trainer. Additionally, both the trainer and trainee may see the purpose of the training programme as a mechanism to change the trainee through an appropriation of prerequisite knowledge and skills, so that she/he may become adept at teaching. In such cases, neither the equality of CD nor its Speaker-led definition of goals is achieved. As Edge (1992: 89) writes:

the question about the trainer/trainee relationship comes down to this: to what extent do trainers see it as their responsibility to change the views and behaviours of trainees? To what extent do trainees see it as the trainers' responsibility to tell or show them what to do and how to do it? As long as one participant is seen as taking responsibility for the views and actions of the other, Cooperative Development is not a real possibility. There would always be a lingering question mark about the honesty of interaction and 
the likelihood of manipulation by the (trainer) Understander towards their own overriding aims. From the other perspective, the (trainee) Speaker might infer guidance where (trainers) Understanders had not meant to give any.

This does not mean that Edge is totally dismissive of a use for $\mathrm{CD}$ in pre-service teacher training, although he sees its application there as marginal (Edge 1992: 89) while generally its use outside of peer-group relations is "messy" (Edge 2011: 127). ${ }^{7}$ However, Edge is adamant that when pre-service teacher training relies upon the trainer as superior assessing trainees as inferiors "Cooperative Development can have little part to play" (Edge 1992: 90). And this may be the greatest problem for CD. In education systems (worldwide) that are market orientated and view success in terms of the results to be obtained through testing (Potulicka, Rutkowiak 2012) and in a society (Poland) where devolved authority and the personal responsibility it entails (Witkowski 2009, 2011) are not, as yet, readily accepted, the outlook for a practice which does not provide approbation through grading and where there is a shared authority, may prove difficult to put into effect. This is especially true in a situation where the "learner" is expected to become the co-author of her/his own development and for the teacher-trainer to accept and support this.

\section{Discussion}

The implementation of a CD model for the teaching practices carried out in IEAS would appear to have advantages. It would solve some of the problems of the present system as perceived by the student-teachers. It would mean a reduction in the amount of paperwork the students would be involved in as it would take away the need for TPJs as tools for monitoring the

7 The example of a non-peer educational situation in which Edge considers $\mathrm{CD}$ to be possible is work with doctoral students. However, Edge is firm in his belief that each case would have to be judged on an individual basis. 
practices they are engaged in (GPP and DP), although none of the administrative paperwork can be reduced due to tax and insurance requirements. It would ensure that student-teachers are given a structured forum to talk about their experiences as they are occurring and to be supported to try and make sense of those experiences in addition to solve any problems that they may encounter. Furthermore, if the system of CD implemented were to involve both the school mentor and the supervisor in the alternating roles of Understander and Observer in support of the student (Speaker), it would enable a positive model of cooperation that would militate against the possibility of bad relations between any of its participants. It would also ensure a close liaison between the mentors (school-teachers) participating in the teaching practices and the supervisor and, therefore, limit discrepancies between the input student-teachers are given on their didactic courses and what they are expected to do in the schools: the supervisor could act as a mediating presence, establishing points of contact, rather than disparity, between what occurs in the classroom and the approach to teaching-learning that is promoted on the didactic course in IEAS. In addition, the problem perceived by one of the authors of this article, where student-teachers lack the ability for deeper reflection in connection with their practices, will be dealt with by the mechanisms innate to $\mathrm{CD}$ which promote and develop reflection in the Speaker (student-teacher).

There is still the question, however, of whether teaching practices for student-teachers based upon CD would actually be feasible. In answer to this, it is the belief of the authors of this article that a number of factors would have to be considered and the potential problems arising from them addressed. The first factor concerns Edge's own reservations concerning the use of $\mathrm{CD}$ in a teacher training environment and the need to resist the temptation, on the part of experienced teachers, to steer student-teachers towards particular ways of viewing and then subsequently dealing with the incidents they experience during their practices. This will need discussion and agreement, as well 
as, perhaps, awareness raising and training for those professionals who take on the roles of Understander and Observer. Student teachers will also have to be part of this awareness raising if they are to understand the mechanisms they are to be involved in, so that they can get the most from the CD encounter for their own development. This awareness raising would necessarily include bracketing, where the people involved in the encounter would suspend their "own beliefs in order to take a fresh perspective" (Ary, Jacobs, Razavieh and Sorenson 2010: 473) of local and conventionally accepted engagement with authority: achieved through engagement in activities that will lead to sensitisation to peer relations between people who may have formerly viewed each other as either superiors or inferiors. This bracketing would also have to be applied to the idea of assessment, which would be replaced by a system that reports upon and is supportive of the individual self-realization of each student-teacher involved in the teaching practices.

Another factor that would have to be examined when considering the implementation of $\mathrm{CD}$, is whether the level of cooperation necessary to carry out awareness raising on to the realization of CD can actually be achieved. This is extremely pertinent if, as previous research has shown (Blaszk 2020), there appear to be varying types of cooperation amongst the different institutions that, between them, form the community within which the teaching practices take place. Not all of these types of cooperation are conducive to joint and coordinated action. Furthermore, engagement in a CD based model of teaching practice would demand a change of working practice for those people (the student-teacher, school mentor and practice supervisor) who take on the roles of Speaker, Understander and Observer. Additionally, because of the necessity for training in the $\mathrm{CD}$ model and the time needed for its application, there may be an increase in the number of hours for all those involved, which may not be acceptable. This is especially true since financial remuneration for those professionals taking part in the practices is at a fixed rate or can be classified as a symbolic payment 
rather than one which reflects the real amount of time and effort that they invest. 8

\section{Conclusion}

It is obvious from the considerations above that a $C D$ based model for the teaching practices in IEAS would not be without problems and would, therefore, need careful consideration and consultation before implementation could be considered. In spite of the perceived problems, however, it appears to be an approach worth considering as the gains for all those concerned, in terms of supported self-development and through this, greater awareness of self leading to empowerment, are strong attributes to be gained and useful for future self-sustaining development - especially for the student-teacher in the environment of teaching but also today, more generally, in the world as a whole. In connection with this, the next step in the continuing development of the teaching practices at IEAS should be to implement a pilot study, where a number of student-teachers and mentors who are genuinely interested come together to take part in developing such a programme.

\section{Acknowledgements}

We would like to give our thanks to the academic staff who, together with the authors, have been involved in running and developing materials for the teaching practices in IEAS over the past decade - Aleksandra Arceusz, Olga Aleksandrowska, Zbigniew Czaja, Joanna Gilis-Siek, Krzysztof Karaś and Renata Zander-Lewandowska.

8 The director and supervisor of practices receive a fixed annual payment related to the number of student-teachers they work with. Mentors in school receive around two Polish złoty (2.26) an hour (approximately 40 cents in relation to the euro or American dollar) for each student with whom they work. Because of this low remuneration many mentors forgo payment altogether for the work that they do. 


\section{References}

Ary, Donald, Lucy C. Jacobs, Ashgar Razavieh, Christine K. Sorenson (2009). Introduction to Research in Education. Belmont, CA: Wadsworth Cengage Learning.

Blaszk, Martin. "Is there a Community of Practice with Regard to Teaching Practices?” (in print).

Dziennik Ustaw Rzeczypospolitej Polskiej (2019). Available at www.prawo.sejm.gov.pl/isap.nsf/DocDetails.xsp?id=WDU20190 001450. Accessed 24.01. 2020.

Edge, Julian (1992). Cooperative Development. London: Longman.

Edge, Julian (2011). The Reflexive Teacher Educator in TESOL: Roots and Wings. New York, London: Routledge.

Freire, Paulo. (1972) Pedagogy of the Oppressed. London: Penguin.

Gabryś-Baker, Dorota. (2012). Reflectivity in Pre-Service Teacher Education. A Survey of Theory and Practice. Katowice: Wydawnictwo Uniwersytetu Śląskiego.

Howard, Amanda, Donaghue, Helen (eds.) (2015).Teacher Evaluation in Second Language Education. London, New York, New Delhi, Oxford, Sydney: Bloomsbury Academic.

Instrukcja Postępowania (2019). Available at fil.ug.edu.pl/studenci/praktyki/ instrukcja_postepowania. Accessed 24.01.2020.

Karpińska-Musiał, Beata (ed.) (2016). W trosce o jakość w ilości. Tutoring oksfordzki w Uniwersyteckie Gdańskim. Kraków: Wydawnictwo Libron.

Karpińska-Musiał, Beata (2017). "The educational rhetoric of empowerment in academic tutoring. The teacher's and student's perspectives". Beyond Philology, 14/1: 205-224.

Lakoff, George and Mark Johnson (1980). Metaphors We Live By. Chicago: University of Chicago Press.

Lankiewicz, Hadrian. (2015). Teacher Language Awareness in the Ecological Perspective. A Collaborative Inquiry Based on Languaging. Gdańsk: Wydawnictwo Uniwersytetu Gdańskiego,

Nunan, David (1989a). Understanding Language Classrooms. Upper Saddle River, N.J.: Prentice Hall,

Nunan, David. (1989b). "A client-centered approach to teacher development". ELT Journal 43/2: 111-118.

Plan studiów (2019). Available at https://fil.ug.edu.pl/sites/default/files/_nodes/strona-filologiczny/12946/files/i_ba-n_19-20 
_filologia.angielska-stacjonarne.pierwszego.stopnia.19-20_06. 09.2019.pdf. Accessed 04.02.2020.

Plan zajęć - stacjonarne (2020). Available at https://drive.google. com/file/d/15KgzI0-k5UFIi5k7YSA5yooQ13qfcPa5/view. Accessed 14.02.2020.

Potulicka, Eugenia, Joanna Rutkowiak (2012). Neoliberalne uwikłania edukacji. Kraków: Oficyna Wydawnicza Impuls.

Praktyki nauczycielskie (2019). Available at https://fil.ug.edu.pl/ wydzial_filologiczny/instytuty/instytut_anglistyki_i_amerykanistyki /praktyki/praktyki_nauczycielskieteaching_work_experience. Accessed 04.02.2020.

Underhill, Adrian (1989). "Process in Humanistic Education". ELT Journal, 43/4: 250-260.

Wallace, Michael J. (1998). Action Research for Language Teachers: A Reflective Approach. Cambridge: Cambridge University Press.

Wallace, Michael J. (1993). Training Foreign Language Teachers: A Reflective Approach. Cambridge: Cambridge University Press.

Werbińska, Dorota (2017). The Formation of Language Teacher Professional Identity: A Phenomenographic-Narrative Study. Słupsk: Wydawnictwo Naukowe Akademii Pomorskiej w Słupsku.

Wilczyńska, Weronika, Anna Michońska-Stadnik (2010). Metodologia badań w glottodydaktyce. Wprowadzenie. Kraków: Avalon.

Witkowski, Lech. (2009). Wyzwania autorytetu. Kraków: Oficyna Wydawnicza Impuls.

Witkowski, Lech (2011). Historia autorytetu wobec kultury i edukacji. Kraków: Oficyna Wydawnicza Impuls.

Wright, Anthony (1987). Roles of Teachers and Learners. Oxford: Oxford University Press. 


\section{Appendix 1}

One of twenty descriptive-reflective observation tasks the students have to use and complete throughout the observations of the DP.

TASK 3. Use of L1 (Polish) and L2 (English) in the classroom (OBSERVE TWO DIFFERENT LESSONS) - to see what language is used in the English language classroom.

a. What language does the teacher use during the lesson - L1, L2 or both?

b. Are there any stages of the lesson or activities, where the teacher decides to use L1 or L2 only? What are the reasons for this?

c. What language do the learners use during the lesson - L1, L2 or both?

d. How does the teacher encourage the learners to use L2?

e. From this particular lesson, what ideas for getting learners to use L2 would you like to use in your own teaching? Why?

\section{Appendix 2}

Self-evaluation questions to be answered after each lesson taught.

\section{SELF EVALUATION}

1. Did the lesson go according to plan? Give details and say why you think this was the case.

2. What was the greatest success of the lesson? Why?

3. What would you change if you were to run this lesson again? Why?

4. How did you feel during the lesson? How do you believe the learners felt during the lesson? Give reasons for your answers.

\section{Appendix 3}

Questions belonging to the Overall Comments sections of the GPP and DP. To be written up after each of the practices have been completed.

\section{OVERALL REFLECTION ON YOUR DIDACTIC PRACTICE}

a) Give your overall impression of your teaching practice. 
b) Briefly describe what you found to be the differences between teaching at the following levels: primary to lower-secondary: $0,1,2,3$; $4,5,6 ; 7,8$.

c) From the observations you carried out and the lessons you taught:

i) Describe the knowledge / skills you have gained from your teaching practice.

Give specific examples.

ii) Describe the things you view to be the successes of your teaching practice.

Give specific examples.

iii) Say what you feel you still need to work on as a teacher.

Give specific examples.

iv) Say what you would do differently if you could do your teaching practice over again. Give specific examples.

d) Other comments relating to this part of your practice that you would like to share.

\author{
Martin Blaszk \\ ORCID iD: 0000-0002-3749-517X \\ Institute of English and American Studies \\ University of Gdańsk \\ ul. Wita Stwosza 51 \\ 80-308 Gdańsk \\ Poland \\ martin.blaszk@ug.edu.pl \\ Joanna Tillack \\ ORCID iD: 0000-0002-4759-899X \\ Institute of English and American Studies \\ University of Gdańsk \\ ul. Wita Stwosza 51 \\ 80-308 Gdańsk \\ Poland \\ joanna.tillack@ug.edu.pl
}

